\title{
Urban Surface Water Quality, Flood Water Quality and Human Health Impacts in Chinese Cities. What Do We Know?
}

\author{
Yuhan Rui ${ }^{1}$, Dafang Fu ${ }^{1}$, Ha Do Minh ${ }^{2}$, Mohanasundar Radhakrishnan 2,* (D), \\ Chris Zevenbergen ${ }^{2}$ and Assela Pathirana 2 (iD \\ 1 School of Civil Engineering, SEU-Monash Joint Research Centre for Water Sensitive Cities, Southeast \\ University (SEU), Nanjing 210096, China; ruiyh1103@163.com (Y.R.); 101002314@seu.edu.cn (D.F.) \\ 2 Water Science \& Engineering Department, IHE Delft Institute for Water Education, \#7 Westvest, \\ 2611AX Delft, The Netherlands; h.do@un-ihe.org (H.D.M.); c.zevenbergen@un-ihe.org (C.Z.); \\ a.pathirana@un-ihe.org (A.P.) \\ * Correspondence: m.radhakrishnan@un-ihe.org; Tel.: +31-647-618-689
}

Received: 11 January 2018; Accepted: 16 February 2018; Published: 26 February 2018

\begin{abstract}
Climate change and urbanization have led to an increase in the frequency of extreme water related events such as flooding, which has negative impacts on the environment, economy and human health. With respect to the latter, our understanding of the interrelationship between flooding, urban surface water and human health is still very limited. More in-depth research in this area is needed to further strengthen the process of planning and implementation of responses to mitigate the negative health impacts of flooding in urban areas. The objective of this paper is to assess the state of the research on the interrelationship between surface water quality, flood water quality and human health in urban areas based on the published literature. These insights will be instrumental in identifying and prioritizing future research needs in this area. In this study, research publications in the domain of urban flooding, surface water quality and human health were collated using keyword searches. A detailed assessment of these publications substantiated the limited number of publications focusing on the link between flooding and human health. There was also an uneven geographical distribution of the study areas, as most of the studies focused on developed countries. A few studies have focused on developing countries, although the severity of water quality issues is higher in these countries. The study also revealed a disparity of research in this field across regions in China as most of the studies focused on the populous south-eastern region of China. The lack of studies in some regions has been attributed to the absence of flood water quality monitoring systems which allow the collection of real-time water quality monitoring data during flooding in urban areas. The widespread implementation of cost effective real-time water quality monitoring systems which are based on the latest remote or mobile phone based data acquisition techniques is recommended. Better appreciation of health risks may lead to better flood risk management. In summary, there is still a limited understanding of the relationship between urban surface water quality, flood water quality and health impacts. This also holds true for Chinese cities. Given the widespread and frequent occurrence of urban flooding, further research into this specific cross-cutting field is mandatory.
\end{abstract}

Keywords: urban water quality; floodwater; human health; water quality monitoring and assessment system

\section{Introduction}

Urban flooding occurs when surface water cannot be drained quickly through drainage systems, streams and rivers. A reduction in permeability, which is a result of an increase of impervious 
surface area (i.e., road, building, parking lot, sidewalk), increases run off, peak discharge and flood frequency [1]. The analysis of urban flood risk is mostly based on an assessment of the underlying hydrological and physical features of an urban area. For example, flood risk maps are usually drawn from an assessment of the recorded and/or predicted rainfall intensities and frequencies in conjunction with a detailed land-use analysis revealing relevant spatial information of the urban fabric [2-4]. In these risk analyses, it is common practice to use the estimated damage due to flooding as a proxy [5]. The estimated flood damage includes the direct and ephemeral impact of flooding, and does not include the associated human health influences which are perennial and implicit.

The quality of flood water is generally overlooked, even in comprehensive flood risk assessments such as the European Union directive on the assessment and management of flood risks [6]. For example, in Section 4, Article 6, Chapter III of the EU directive 2007/60/EC [6] on the assessment and management of flood risk, the various aspects of flooding pertain to flood extent, water depth, and flow velocity, whereas there is no mention of flood water quality [6]. This is due to the fact that deterioration of surface water quality is considered acceptable as an exception during flooding [7]. Floods also endanger human health through wound infections, diarrheal illness and post-traumatic stress disorder in evacuees [8]. This paper aims to collate and analyze research papers which address the link between urban flooding, urban water quality and public health.

The paper presents an overview and a comparison of studies on public health, urban flooding and surface water quality from a global perspective, but with emphasis on China. The latter is relevant in the context of contemporary flood resilient city initiatives such as the "Sponge Cities" program, which aims to enhance infiltration, evapotranspiration, and the capture and reuse of storm water in Chinese cities [9]. The general objectives of the Sponge Cities concept are to 'restore' the city's capacity to absorb, infiltrate, store, purify, drain and manage rainwater and 'regulate' the water cycle as much as possible to mimic the natural hydrological cycle. This paper is divided into five sections: (i) background, where an overview of research on urban flooding, surface water quality and public health is presented; (ii) methodology section which elaborates on the literature review procedure; (iii) results section where the assessment outcomes are presented; (iv) discussion section were the results are discussed in relation to the contemporary urban context in China; and (v) conclusion.

\section{Background: Connections between Urban Surface Water, Floods and Human Health}

A wide spectrum of contaminants such as heavy metal (copper, zinc, lead, and chromium), halogenated aliphatics (gasoline), polycyclic aromatic hydrocarbons (chloroform, benzene, etc.), pesticides, phenol (chlordane, lindane, etc.), and associated macro pollutants (phosphorus, nitrogen, etc.) accumulate in the urban environment (air, land and water bodies) due to local emissions of these contaminants driven by urbanization (c.q. transportation and power production) and industrial development [10]. These contaminants are known to be associated with cancer, cardiovascular, gastrointestinal, kidney, liver and neurological diseases [11]. A significant fraction of these contaminants eventually accumulates in bodies of water, such as lakes, rivers and streams, in the event of runoff or flooding after precipitation [12]. An additional source of contamination of these water bodies are the outflows from sewage treatment plants leading to eutrophication [13].

Fluvial and pluvial flooding can impact the urban surface water quality. However, the effect of inundation on urban surface water quality is usually temporary. Depending upon the type and concentration of the contaminants of the receiving surface waters and flood water and their dilution rate, inundation may improve or deteriorate the water quality of the receiving surface waters [14]. Suspended Solids (SS), Biochemical Oxygen Demand (BOD), Chemical Oxygen Demand (COD) and Dissolved Organic Carbon (DOC) usually tend to increase during the flood phase and then return to pre-flood levels [15]. In Botic Creek, Prague, agglomeration, that is, heavy metal remobilization from sediments, during flooding has been observed, which has led to an increase in the heavy metal concentration in the surface waters. After the flood water receded, the concentration subsequently decreased to a level lower than the former level, probably because of depletion of the adsorbed fraction 
of heavy metals due to remobilization, followed by removal of these constituents via surface water flow. Though urban flooding may have negative impacts (as it may serve as a source of contamination), it also may have positive impacts on the surface water quality (as it may cause dilution and/or removal of contaminants) [16]. It follows from the above that floodwater may have an impact on the urban surface water quality. These impacts result in temporary changes in contaminant concentration of urban surface waters. Given the dynamic and temporary nature of flood water, continuous monitoring is required to better assess these impacts. This certainly holds for the long-term impacts.

There is a growing body of research directed to assessing the contaminant concentrations of storm water. For example, a nine-year long monitoring program of urban storm water runoff in Vilnius, Lithuania, has revealed that the mean values of suspended solids (SS) and total petroleum hydrocarbons (TPH) are most likely to exceed the permissible limits [17]. The results from an investigation of the Liangshui River in Beijing has indicated that the concentration of $\mathrm{NH}_{4}-\mathrm{N}$ increased rapidly during an intense rainfall event [18]. An assessment of the water quality of runoffs from an urban road in in Guangzhou showed $\mathrm{NH}_{4}-\mathrm{N}$ concentrations around $30 \mathrm{mg} / \mathrm{L}$ [19], which indicates that road runoff is a significant contributor to pollution of urban water bodies [18]. Contaminations associated with traffic, such as toxic metals $\mathrm{Zn}, \mathrm{Cr}, \mathrm{Cu}, \mathrm{Hg}, \mathrm{Ni}, \mathrm{Cd}$ and $\mathrm{Pb}[20]$ and polycyclic aromatic hydrocarbons (PAHs), can lead to a deterioration of the water quality of urban rivers [21]. However, biological oxygen demand (BOD) and chemical oxygen demand (COD) from road runoffs does not seem to result in urban surface water concentrations which exceed the acceptable limits [16]. In this literature review no further research has been found which provides additional information on the correlation between the water quality of urban water bodies and runoff [15]. With respect to the sediment quality of urban water bodies, it should be noted here that high concentrations of heavy metals and PAHs concentrations have been found in sediments of urban small streams [14]. These high concentrations may adversely impact the surface water quality in the longer term. However, due to their complexity, our understanding of the underlying desorption and weathering processes causing mobilization of these contaminants is still very limited [14].

Natural disasters, namely floods, droughts and earthquakes often have a dramatic impact on human society, such as loss of lives, and economic and ecological losses [22]. In the past two decades, our understanding of these risks and how to manage them have increased significantly. However, very little is known about the impacts of these disasters on human health. This especially holds true for those associated with flooding. It is still common practice, to express the severity of a flood disaster by the number of deaths and injured [23]. The impacts of flooding on human health encompassing the physical and psychological effects, are excluded from these assessments as they are often remote and difficult to assess.

A review investigating the literature on flooding and human health impacts before 2012, indicated that there has been an increase in disease outbreaks, such as hepatitis E, gastrointestinal disease and leptospirosis, particularly in areas with poor hygiene and displaced populations [11]. For instance, in Bangladesh, with seventy percent of the population living in flood prone low-land regions, diarrhea is the major illness cause, which accounted for thirty-five percent of the 45.000 hospital admissions and twenty-seven percent of 154 reported deaths [23]. The most common pathogens causing waterborne outbreaks that have been reported during extreme water-related weather events, are Vibrio spp. (21.6\%) and Leptospira spp. (12.7\%) [23].

Also, Cann et al. (2013) [24] concluded that outbreaks of waterborne infectious disease do occur after an extreme water-related weather event in both developed and developing countries. A study on the quality of urban floodwater in Utrecht, the Netherlands, has shown that the floodwater quality is similar to that of sewage [25]. This is to be expected as some of the old urban areas have a combined sewer system which overflows during periods of excessive rainfall, resulting in a pollution outbreak. Similarly, a study on the quality of floodwater in Can Tho City, Vietnam, has shown that the pathogen and contaminant levels of the flood water are almost as high as that of the sewers [26]. From Figure 1 it can be seen that the Salmonella concentration in flood water are as high as in sewage and hence 
wading through flood water of this type is likely to affect health [26]. Hence flood water quality is a concern in both developed and developing countries.

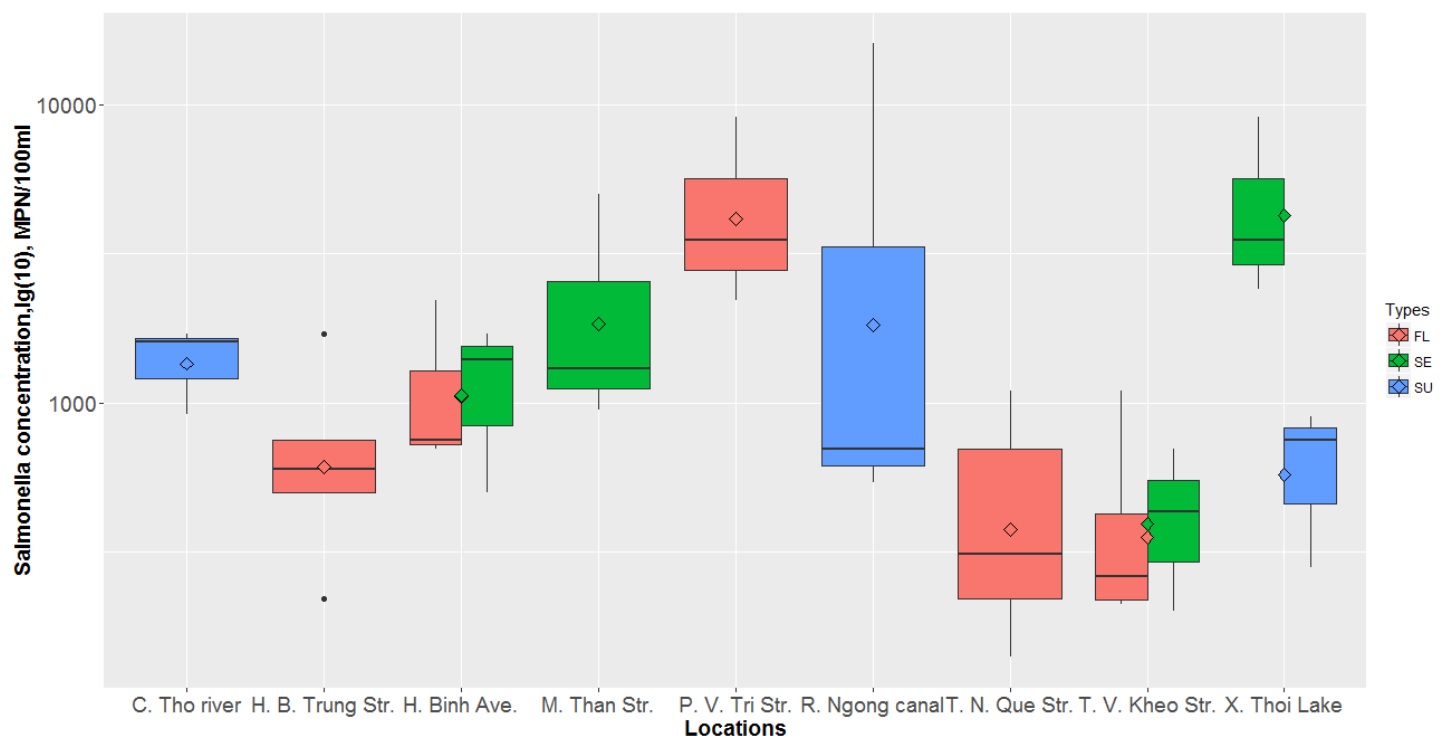

Figure 1. Salmonella concentration in flood water (FL), sewage (SE) and surface water (SU) bodies in Can Tho observed during October 2013 flood event [26].

\section{Methodology/Approach}

In order to review relevant published literature around the world, especially for China, databases comprising scientific literature on the crossroad of human health, urban flooding and urban water quality were selected and keyword searches were performed. The detailed research methodology is presented in Figure 2.

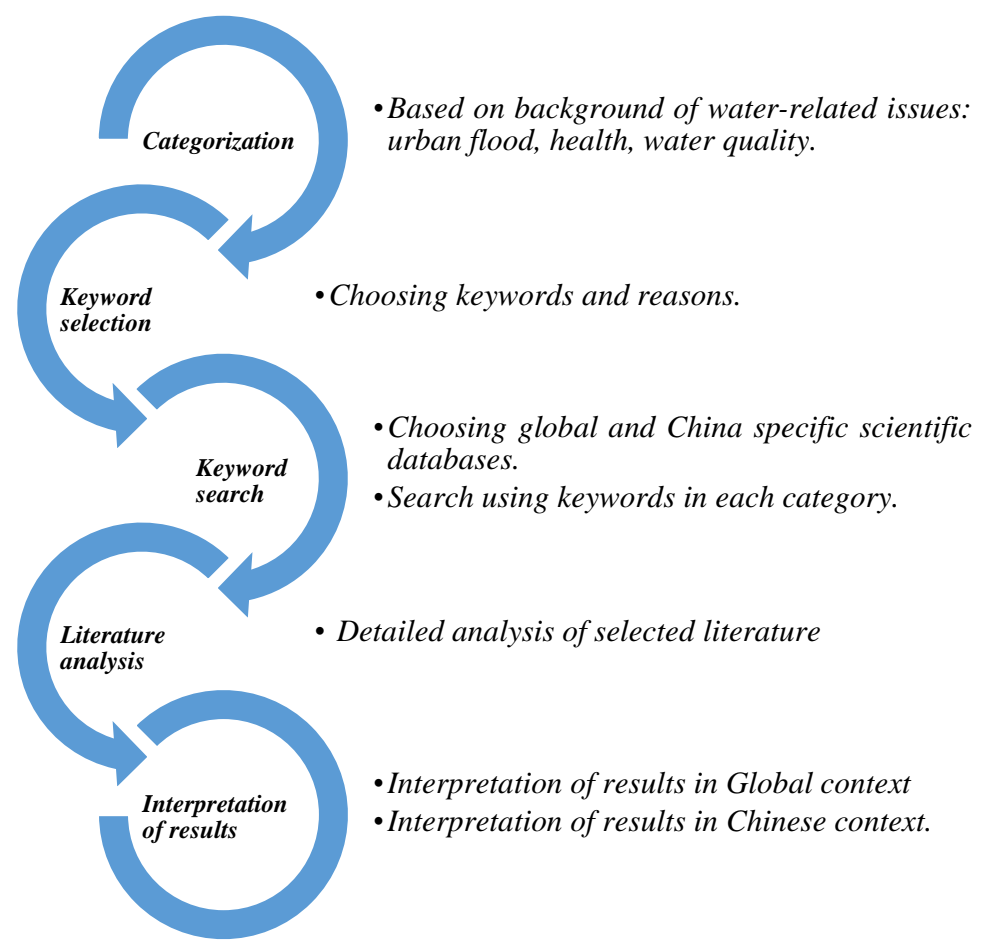

Figure 2. Review methodology. 
Categorization: As the main focus of the paper is to assess flood water impacts on human health, the literature in the following broad categories were identified for further assessment: (i) urban water quality; and (ii) urban flood and human health.

Keyword identification: In order to narrow down the search, specific keywords were used to identify and filter the literature for a thorough assessment. The keywords pertaining to water quality are: "drinking water quality", "potable water quality", "urban water quality", "flood water quality", "urban water quality and health", "flood water quality and health" and "floodwater quality". The keywords pertaining to urban flood and human health are: "health risk", "flood", "urban", "water quality", "waterlogging and flood" and "urban stream (creek) water quality".

Keyword search: A keyword search was executed across a variety of scientific journals and international databases and Chinese libraries to ascertain the global context and the Chinese context, respectively, on public health during flooding. International scientific journal repositories, such as Water Research, Water Science and Technology, Environmental Monitoring and Assessment, Journal of Hydrology and Water, were accessed and searched using the keywords mentioned in Step 2 and the number of identified papers were further downsized using a detailed assessment. Also, Chinese libraries, such as Chinese Science Citation Database (CSCD) and Chinese Core Journal of Peking University [27] were also assessed and the number of papers were narrowed down using the keywords.

Literature analysis: The selected literature (following from the keywords search) between 1999 and 2017 was assessed in detail based on the content and geographical focus of the literature. In this manner, the number and geographical location of the studies reported in the literature on drinking/potable water quality; flood water quality; urban water quality; flood and health; and, urban water and health have been assessed.

Presenting and interpreting results: After assessing the number and location of these studies the papers were analyzed and collated.

This research used the following definitions for urban surface water, flooding, surface water quality, flood water quality, drinking water quality and urban water quality: (i) Urban surface water pertains to the water bodies in urban areas such as ponds, lakes, streams, canals, rivers, swales and wetlands; (ii) flooding is the undesirable consequence that pertains to the covering or submerging of normally dry land with a large amount of water; (iii) surface water quality pertains to the water quality of the surface water bodies in urban areas; (iv) flood water quality pertains to the water quality of flood water in urban areas; (v) drinking water quality pertains to the quality of drinking water in the drinking water distribution systems and in places where drinking water is consumed; and (vi) urban water quality pertains to the quality of drinking water, quality of surface bodies and quality of flood water in urban areas.

\section{Results}

The keywords used for the literature search and few papers based containing those keywords are presented in Table 1. The number of papers published in each year between the year 1997 and 2017, containing the keywords, are presented in Figure 3. It can be seen from Figure 3 that the number of publications containing the five keywords has increased over time.

Table 1. Select literature based on keyword search.

\begin{tabular}{cc}
\hline Keywords & Literature \\
\hline Drinking/potable water quality & {$[28-37]$} \\
Flood water quality & {$[38-47]$} \\
Urban water quality & {$[48-57]$} \\
Flood water \& health & {$[58-67]$} \\
Urban water \& health & {$[68-77]$} \\
\hline
\end{tabular}




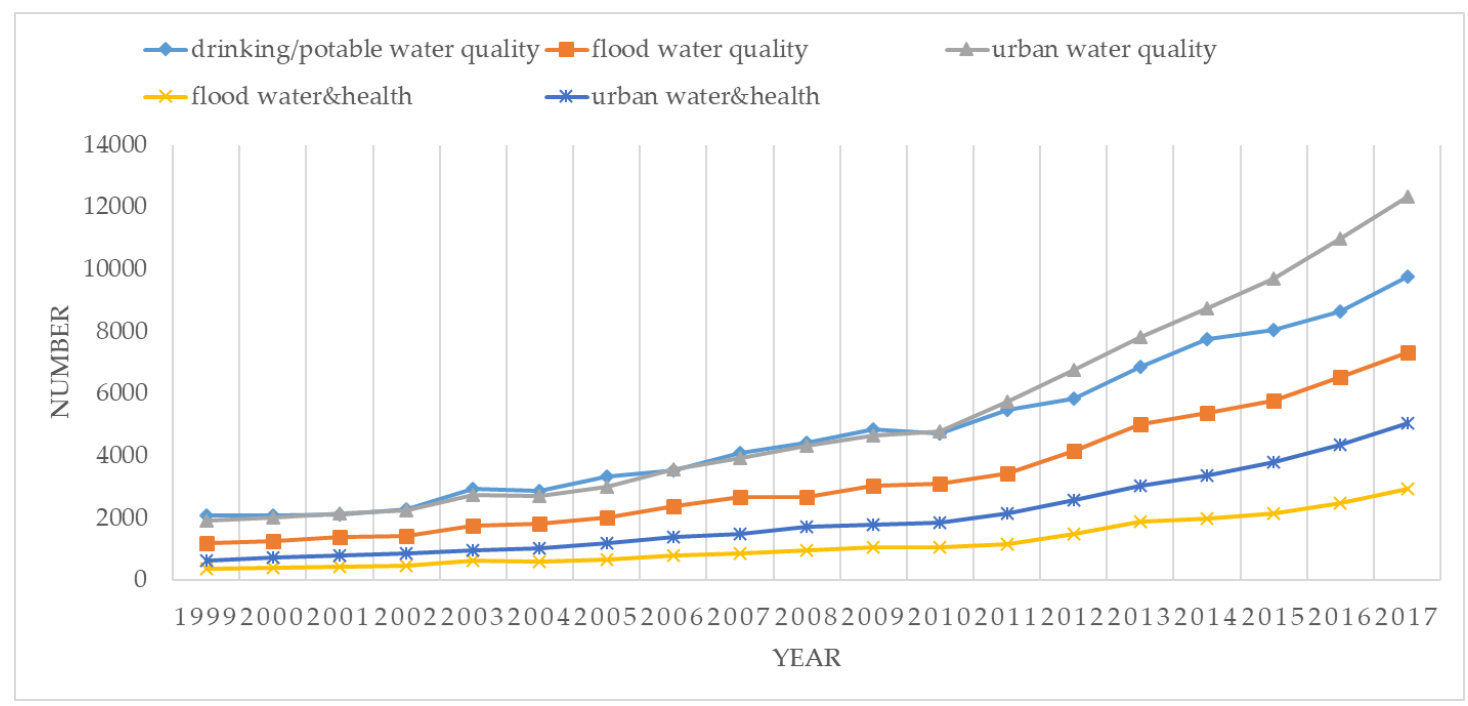

Figure 3. Number of papers published in each year on urban surface water, human health and flooding based on keyword search.

From Figure 3 it can be seen that there is no significant increase in publications related to drinking/potable water quality and urban water quality between 1999 and 2010 with the number of publications containing these two keywords increasing from 2000 to 4000 in this period. Figure 3 also shows that there has been an increase in emphasis on urban water quality related research after 2011 as the number of publications attributed to urban water quality is steadily increasing. The latter can be attributed to the developments in technology and/or a (global) rising concern about water security $[78,79]$. Also, the number of studies on flood water quality are less than those on urban water quality. This may be due to the following practical reasons: (i) floods are infrequent and short lasting, which complicate the design and management of a flood water quality monitoring system; and (ii) flood events pose a threat to human life, hence it can be a risky undertaking to collect flood water samples in order to assess the flood water quality in real time [26]. As a result, the number of studies comprising both water quality of urban water and health and water quality of flood and human health are much less compared to the number of studies on the water quality of drinking water, flood water and urban surface water.

Research publications from five journals (Water Research, Water Science and Technology, Environmental Monitoring and Assessment, Journal of Hydrology and Water) in the field of human health impact were retrieved, which include direct exposure to flood water (Table 2). Three papers from Water Research and one paper from the Journal of Hydrology have addressed the human risk due to direct exposure to floods $[25,58,80,81]$. Most papers in these journals concern the health risk from potable water or agricultural water $[82,83]$, which are due to direct and indirect consumption of water and cutaneous absorption. A paper on the analysis of floodwater quality in Utrecht, the Netherlands, indicates that fecal indicator organism concentrations, such as Campylobacter, Cryptosporidium and Giardia, are similar to those found in raw sewage under high-flow conditions [25]. In the Netherlands the risk for children of infection when exposed to flooding originating from combined sewers, storm sewers and rainfall generated surface runoff are $33 \%, 23 \%$ and $3.5 \%$ respectively; whereas the risk of infection for adults are $3.9 \%, 0.58 \%$ and $0.039 \%$ respectively [58]. A study on water quality from a water plaza in Rotterdam, the Netherlands, shows that the Campylobacter infection risks for children playing in a water plaza are higher than the annual average figure for the general population through all exposure pathways [80]. Mosquito breeding in rain water harvesting systems has been reported as a significant public health threat in Melbourne, Australia [84]. Mosquito breeding in storm water storage systems is also a public health threat in China [85]. All these health risks are likely to increase 
with an increase in frequency and severity of urban flooding due to an increase of intense rainfall events and temperature driven by climate change [86].

Table 2. Research papers connecting flooding and health risk in select journals.

\begin{tabular}{cccc}
\hline \multirow{2}{*}{ Journal } & \multicolumn{3}{c}{ Type } \\
\cline { 2 - 4 } & Health Risk & Flood \& Health Risk & Direct Exposure to Flood Water \\
\hline Water Research & 2110 & 212 & 3 \\
Water Science and Technology & 398 & 51 & 0 \\
Environmental Monitoring and Assessment & 5706 & 747 & 0 \\
Journal of Hydrology & 406 & 224 & 1 \\
Water & 32 & 3 & 0 \\
\hline
\end{tabular}

Numerous research papers on floodwater quality in China, with the keywords "urban", "water quality", "urban runoff water quality", "waterlogging" and "flood" were retrieved using the data from CSCD and the Chinese core Journal of Peking University [28]. Three studies were found on urban floodwater quality. Two studies pertain to mosquito breeding in Shanghai and Ningbo and one study is about runoff quality in $\mathrm{Xi}^{\prime}$ an $[85,87,88]$. The geographical distribution of these studies is presented in Figure 4. There have been 32 studies on urban runoff water quality. None of these pertain to urban flooding situations [89-120]. Although most of these studies focus on cities in the south-eastern part of China, there has been four studies involving cities in other regions of the country, like Lanzhou [111], Baoji [115], Chongqing [109] and Urumqi [117]. The urban water quality monitoring reported by these publications are relevant to the major parameters, SS, Nitrogen $(\mathrm{N})$, Phosphate $(\mathrm{P})$ and COD/BOD, which are associated with environmental problems and not health risk [105-107,110]. Two hundred and two research papers were found using the keywords, "urban", "river (stream, creek)" and "water quality" of which 145 papers included urban water quality. China (Figure 5).

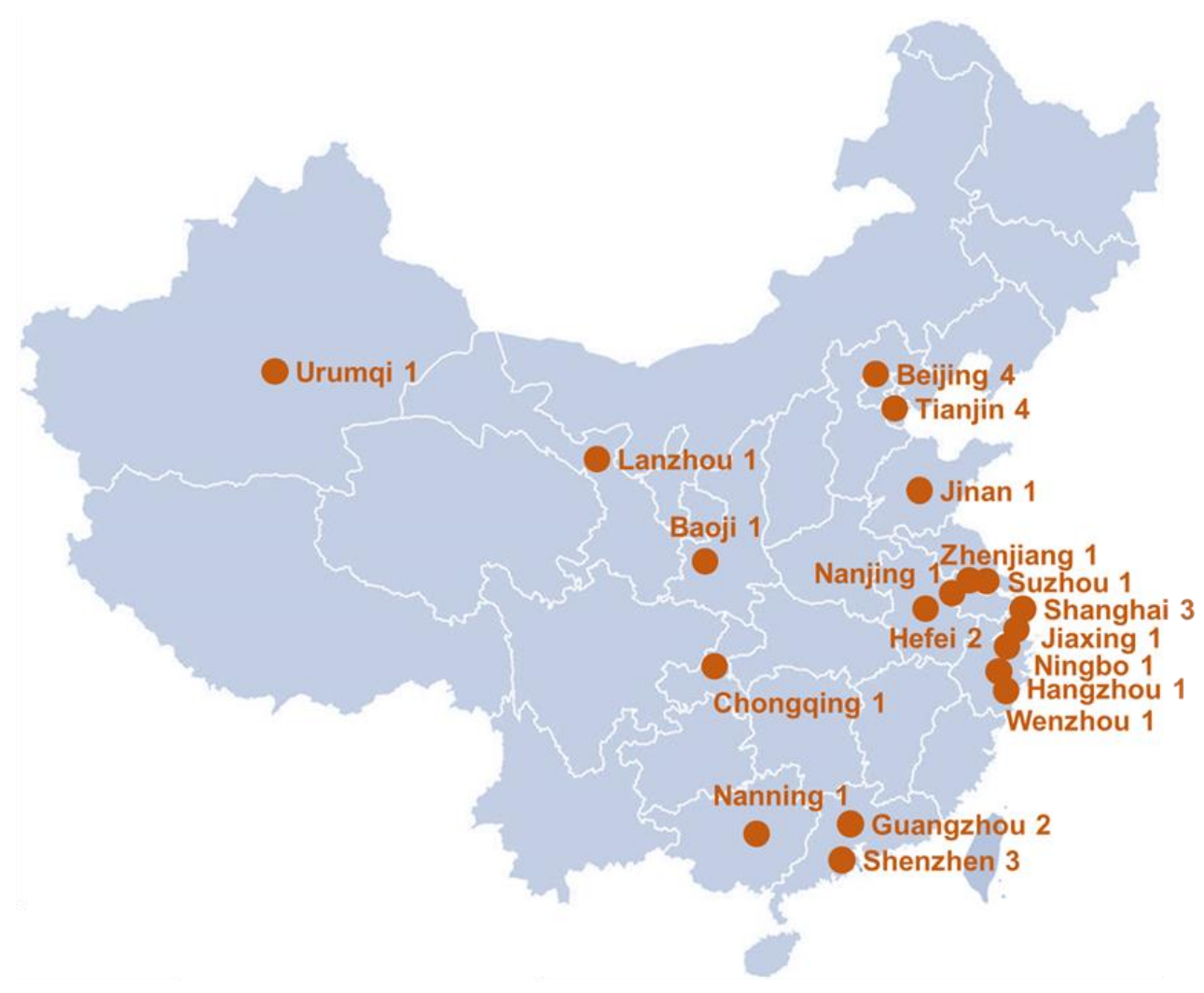

Figure 4. Distribution of urban runoff quality studies in China. The numbers after the city names indicate the number of runoff quality research papers based on the city. 


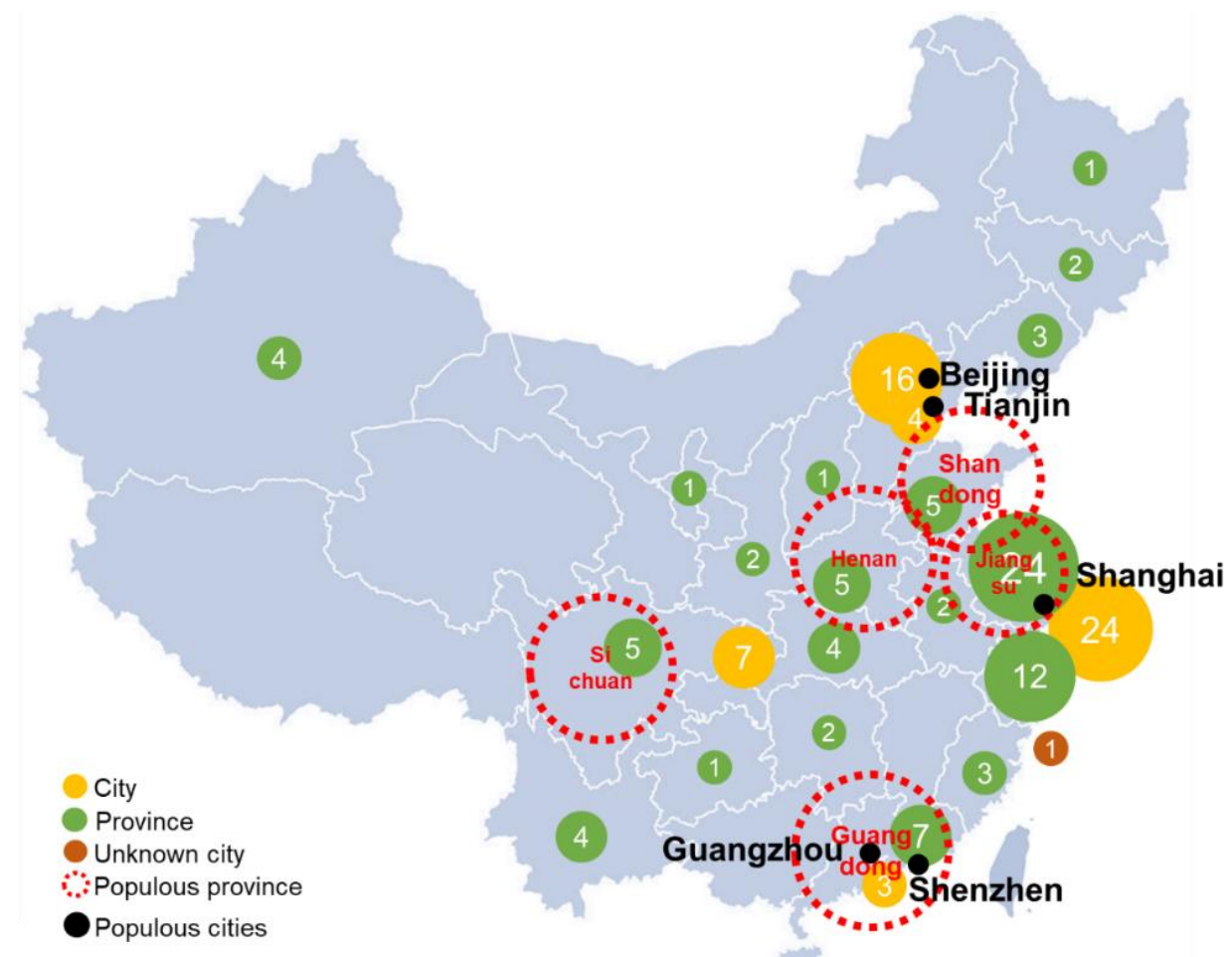

Figure 5. The distribution of urban water quality and population.

From the assessment, it can be seen that the study locations are unevenly distributed, with most of the studies in the densely populated eastern part of China (Figure 5). Most of the studies have a focus on the water quality problems of Shanghai and Beijing, and predominantly include physical and chemical parameters, such as N, P, DO and COD/BOD (Figure 6). These macro-constituents have relevance to environmental health rather than health risk. There are a few studies that use other parameters, i.e., environmental hormones [121], neuroactive substances [122], viruses and Escherichia coli [123].

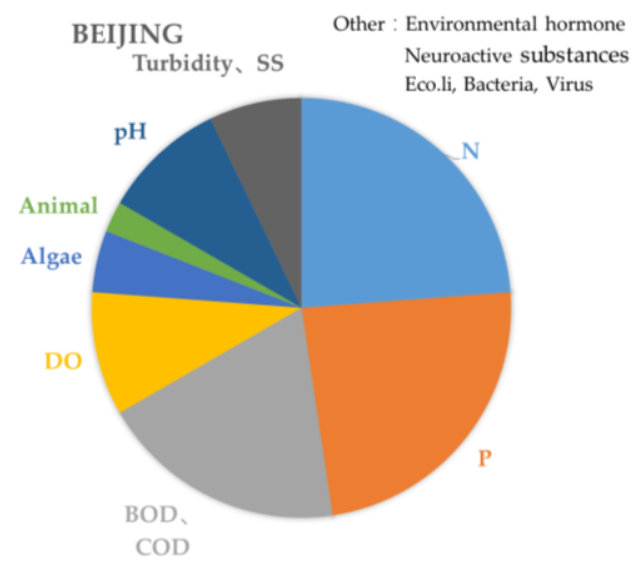

(a)

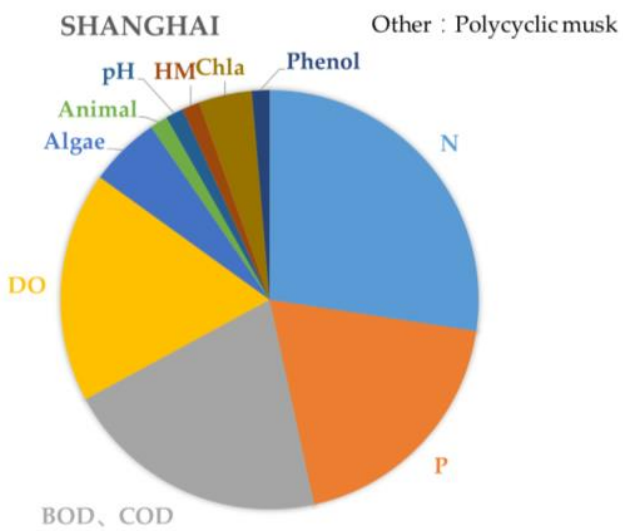

(b)

Figure 6. Cont. 


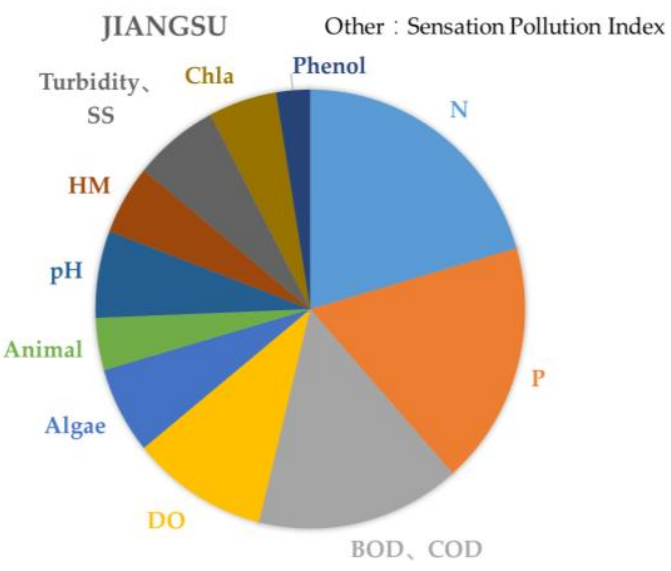

(c)

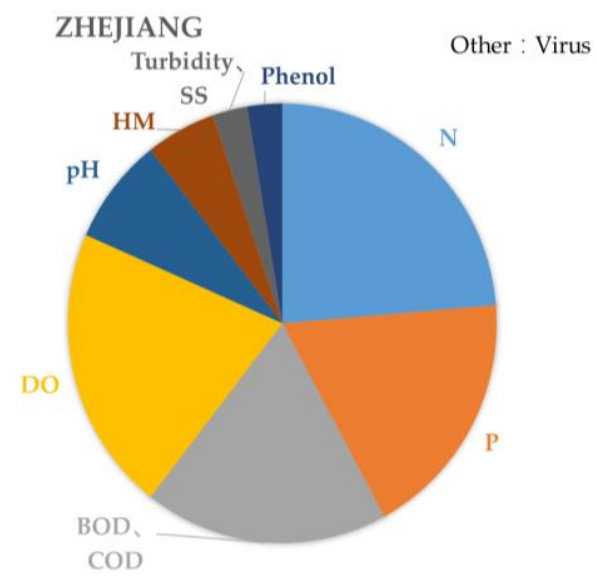

(d)

Figure 6. Water quality parameters assessed in four major cities and provinces of China. (a) Beijing, (b) Shanghai, (c) Jiangsu, (d)Zhejiang.

Although the most populated provinces are Guangdong, Henan and Shandong, the two provinces where water studies are predominant are Jiangsu and Zhejiang (Figure 6). Though these provinces are relatively less urbanized, they are highly industrialized. This might be the reason for more water quality studies being done in these two provinces.

\section{Discussion}

Floods are omnipresent but infrequent and short lasting, which may explain the practical constraints to timely collection of samples. This explains in part the lack of flood water quality data. From a global perspective, flood water quality assessments have been carried out only in few countries (Figure 7). In Bangladesh, Vietnam, Sudan, Nigeria, Thailand and Indonesia, which are prone to flooding, the number of studies on floodwater quality is less than in developed countries such as United Kingdom, Australia and the Netherlands [25,38-43,61]. There are studies in Dhaka, Bangladesh which model health risk from flooding exemplified by cholera, based on the mixing of pollutants in flood water using a deterministic hydraulic model and data on human vulnerability using dose response functions [124]. Initiatives such as Preparing for Extreme and Rare events in coastal regions (PEARL) is developing holistic flood risk assessment for coastal communities that also include health risks due to flooding [125]. Also, from Figure 7 it can be seen that there is no flood water quality data publicly available in China. Availability of funding or enforcement of strict water quality regulations may explain why more studies have been conducted in developed countries [126,127]. Whereas a lack of resources, delegation of resources to other needs such as evacuation or emergency management and weak enforcement of water quality monitoring guidelines can be attributed to the observed lack of water quality assessment studies and water quality monitoring during flood events in developing countries [26]. The absence of water quality studies in the western part of China does not mean that there are no water quality problems in this region of China $[128,129]$. Flooding is a problem in China $[130,131]$ and the lack of flood water quality studies in China is glaring (Figure 7). 


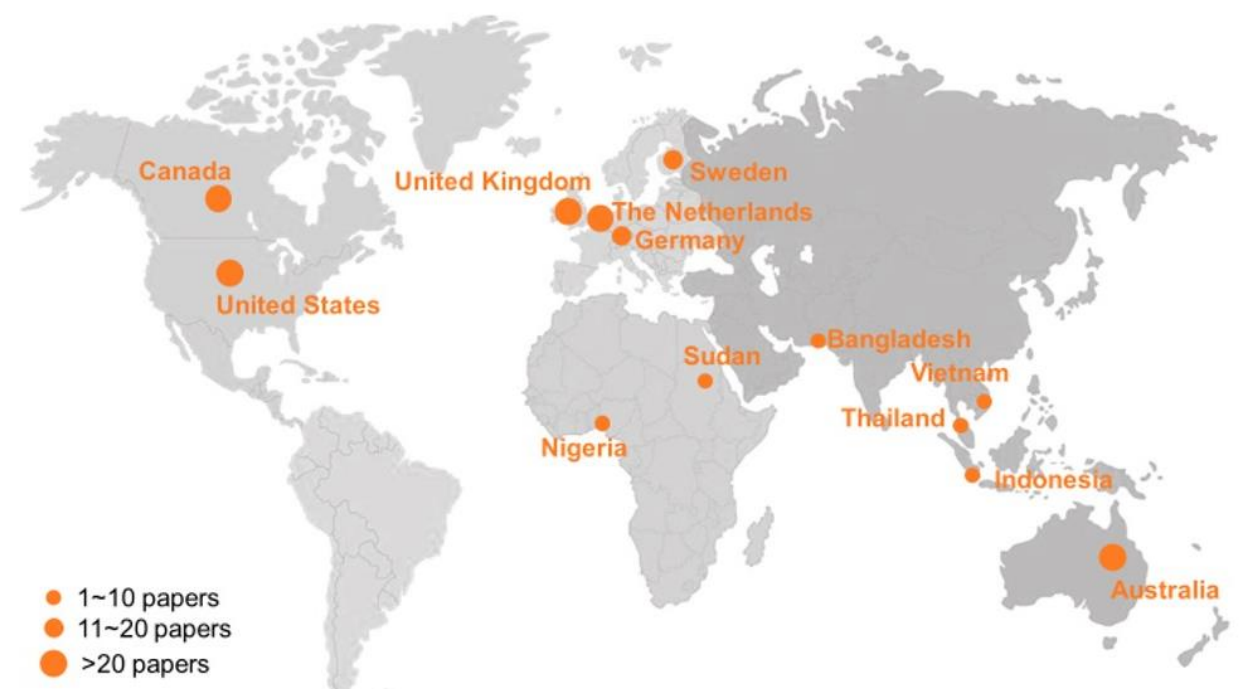

Figure 7. Geographical distribution of flood water quality assessments in the world.

As the central and western parts of China are being industrialized, urban environmental problems might increase in the near future and are likely to be exacerbated by climate change. Hence, it is likely that more research and initiatives will be dedicated to urban water quality in these regions of China in the near future. Urban water quality monitoring assessment and public health assessment can be linked to the Sponge City initiative as this program aims to guide cities to follow a sustainable pathway of urban development and transformation where water quality improvement is an essential component [132]. In optima forma, the water quality component also captures human health aspects during flooding. The cities selected in 2015 and 2016 as pilot Sponge Cities are presented in Figure 8 [132]. Comparison of Figures 6 and 8 reveals that Sponge City pilot studies on urban water quality are concentrated in the Eastern region. These studies are likely to provide a wealth of data which can feed into a knowledge base on urban water quality in the coming years.

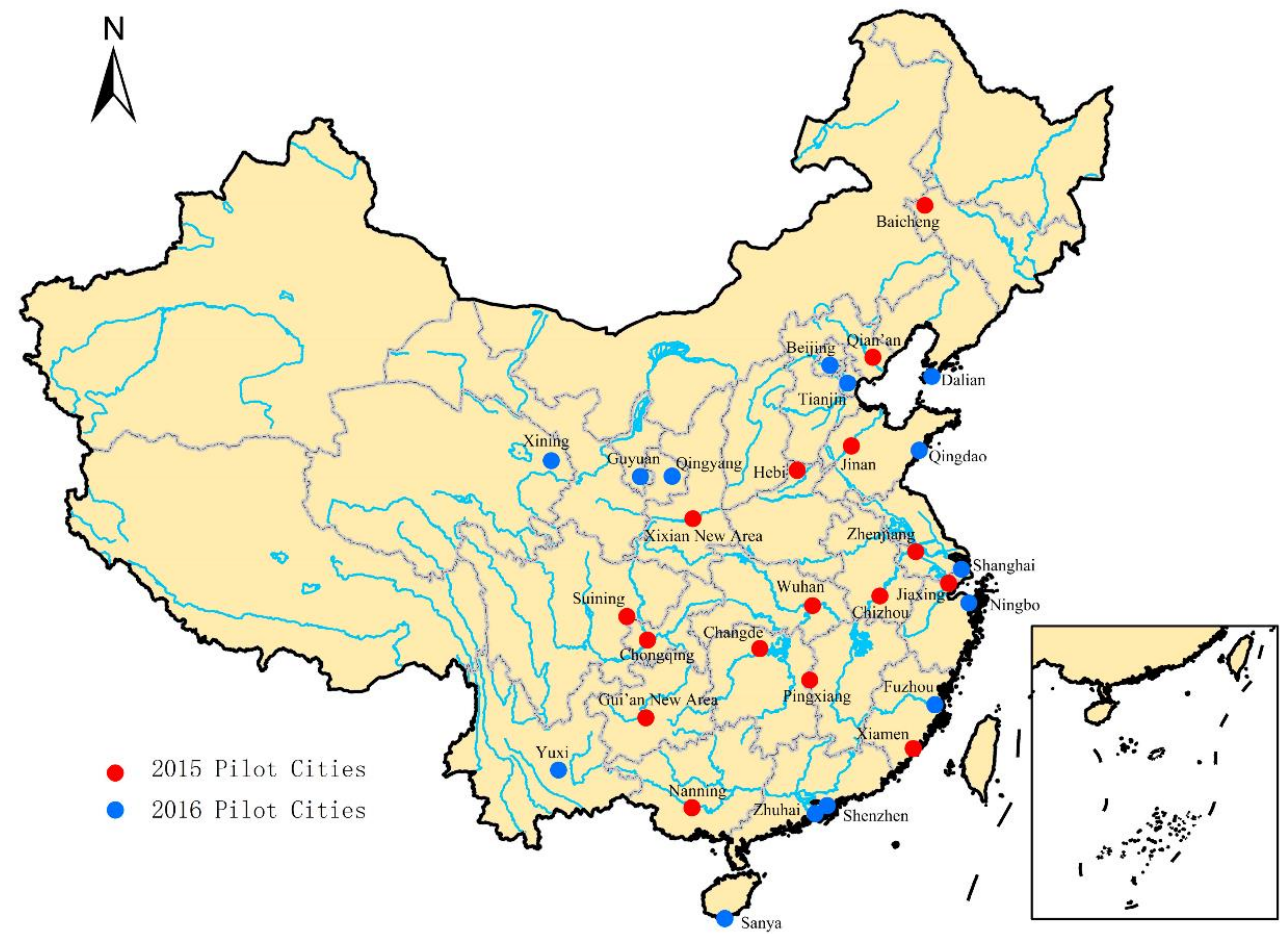

Figure 8. Location of Sponge City pilots in China (Source: Li et al. (2017)) [132]. 
Another explanation for the current knowledge gap is that there is still little attention to the health impacts associated with floods because these impacts are generally remote and difficult to assess. Monitoring flood water quality in real time is a labor-intensive process which needs elaborate planning arrangements for anticipating flooded areas, collecting samples, transporting them to labs and ensuring the safety of the personnel involved [26]. Some of the provincial capitals in China such as Nanjing, Chongqing, Beijing, Guangzhou, Shanghai and Hangzhou have started extensive water quality monitoring programs [133-138]. Real-time water quality data from 148 locations across China are now available [139].

Recent advances in in situ water testing technology (such as smartphone-based sensors) in conjunction with online data platforms allowing for rapid data analysis, visualisation and decision-making, will further accelerate the deployment of real-time water quality monitoring systems during flood events in Sponge Cities [140]. These developments will ultimately contribute to a rapid increase in our understanding of the complex inter-relationship between water quality, flooding and public health in pilot Sponge Cities. In addition to real-time flood water quality monitoring, flood water quality can be simulated using models such as EPA Storm Water Management Model (SWMM) [141] and Delft-FEWS [142] open data handling platform, which can be used to forecast water quality. The water quality models validated and caliberated using real-time water quality systems can be used in the context of the Sponge Cities. This can be futher extended to assess the microbal risk to human health at a particular location or throughout the city based on methods such as Quantitative Microbial Risk Assessment (QMRA) [143,144] based on hazard, dose-response, exposure, and risk characterization [145].

\section{Conclusions}

This paper has assessed the scientific literature on the inter-relationship between surface water quality, flood water quality and human health in urban areas around the world, and China in particular. Even though flooding, surface water and human health in urban areas are interconnected, this assessment reveals that the importance of flood risk and health impacts have generally been ignored and underestimated. There is a growing body of evidence that the health impacts due to flooding are becoming more important as more people are being exposed to floodwater every year. From our assessment, it is clear that (i) most of the studies are focused on either water quality or health; (ii) the number of cross-cutting studies on flood water quality and health are limited, but growing; and (iii) the effects of flood water quality on health impacts in urban areas are still largely unknown, but are receiving more attention in assessments of health risks in cities. However, based on this study, it can be assumed that the health impacts in urban areas with high frequency low impact (direct damage) flood events are more severe than those with low frequency high impact events. The first type of event is often ignored in flood risk assessments. This study also reveals that water quality assessment studies in China have focused on the highly populated south-eastern cities, albeit with particular attention to the water quality parameters which have relevance to environmental assessments. These parameters have no or limited value to health impact assessments. Expanding the current water quality monitoring activities with the flood water quality parameters required to assess human health impacts in China is needed and this is in alignment with the ambition of the Sponge Cities program. Hence, flood water quality monitoring should be an integral part of the Sponge City program. Though collection and sharing of flood water quality data are a challenge, the Sponge Cities program provides an opportunity to make a leap forward in the application, testing, rolling out and upscaling of innovative flood water quality monitoring technology and health impact analyses throughout China. Better appreciation of flood induced health risks will lead to better flood risk management.

Acknowledgments: This work was supported by Southeast University (SEU), Nanjing, China; and IHE Delft Institute for Water Education, The Netherlands.

Author Contributions: The paper is based on the results obtained from the research of Yuhan Rui, which was done for the partial fulfilment of requirements for the Master of Science degree at the Southeast University under 
the supervision of Dafang Fu and Chris Zevenbergen. The first draft was written by Yuhan Rui, Ha Do Minh and Mohanasundar Radhakrishnan. Dafang Fu, Chris Zevenbergen and Assela Pathirana helped to review and improve the paper.

Conflicts of Interest: The authors declare no conflict of interest.

\section{References}

1. Konrad, C.P. Effects of Urban Development on Floods. Available online: https:/ / pubs.usgs.gov/fs/fs07603/ (accessed on 21 February 2018).

2. Zhang, C.-L.; Chen, F.; Miao, S.G.; Li, Q.C.; Xuan, C.Y. Influences of urbanization on precipitation and water resources in the metropolitan Beijing area. In Proceedings of the 21st American Metrological Society Conference on Hydrology, San Antonio, TX, USA, 17 January 2007.

3. Huong, H.T.L.; Pathirana, A. Urbanization and climate change impacts on future urban flood risk in Can Tho city, Vietnam. Hydrol. Earth Syst. Sci. 2013, 17, 379-394. [CrossRef]

4. Chen, Y.; Zhou, H.; Zhang, H.; Du, G.; Zhou, J. Urban flood risk warning under rapid urbanization. Environ. Res. 2015, 139, 3-10. [CrossRef] [PubMed]

5. Olsen, A.S.; Zhou, Q.; Linde, J.J.; Arnbjergnielsen, K. Comparing Methods of Calculating Expected Annual Damage in Urban Pluvial Flood Risk Assessments. Water 2015, 7, 255-270. [CrossRef]

6. European Parliament; Council of the European Union. Directive 2007/60/EC of the European Parliament and of the Council of 23 October 2007 on the Assessment and Management of Flood Risks (Text with EEA Relevance). Available online: http:/ / data.europa.eu/eli/dir/2007/60/oj (accessed on 21 February 2018).

7. European Parliament; Council of the European Union. Directive 2000/60/EC of the European Parliament and of the Council of 23 October 2000 Establishing a Framework for Community Action in the Field of Water Policy. Available online: http:/ / eur-lex.europa.eu/legal-content/EN/TXT/?uri=CELEX:32000L0060 (accessed on 21 February 2018).

8. Horton, R. Extreme rain, flooding, and health. Lancet 2017, 390, 1005.

9. Liu, D. Water supply: China's sponge cities to soak up rainwater. Nature 2016, 537, 307. [CrossRef] [PubMed]

10. Novotny, V. Water Quality: Diffuse Pollution and Watershed Management; John Wiley \& Sons: New York, NY, USA, 2002.

11. Alderman, K.; Turner, L.R.; Tong, S. Floods and human health: A systematic review. Environ. Int. 2012, 47, 37-47. [CrossRef] [PubMed]

12. Chiew, F.H.S.; Mcmahon, T.A. Modelling runoff and diffuse pollution loads in urban areas. Water Sci. Technol. 1999, 39, 241-248.

13. Wang, A.L.; Sun, X.; Chen, Q.K.; Yang, L.Y. Effect of ammonia in the tailwater from wastewater treatment plant on the growth of myriophyllum spicatum. Chin. J. Ecol. 2015, 34, 1367-1372.

14. Nabelkova, J.; Kominkova, D.; Jirak, J. The impact of highway runoff on the chemical status of small urban streams. Urban Environ. 2012, 19, 297-306.

15. Hayashi, H.; Tasaki, M.; Uchiyama, N.; Morita, M. Water quality and pollution load during flood and non-flood periods in an urban tidal river. J. Hydraul. Eng. 2013, 69, I_1723-I_1728. [CrossRef]

16. Nábelková, J.; Stastná, G.; Komínková, D. Flood impact on water quality of small urban streams. Water Sci. Technol. 2005, 52, 267-274. [PubMed]

17. Karlavičienè, V.; Švedienè, S.; Marčiulionienè, D.E.; Randerson, P.; Rimeika, M.; Hogland, W. The impact of storm water runoff on a small urban stream. J. Soils Sediment. 2008, 9, 6-12. [CrossRef]

18. Yan, L.; Bi, J.L.; Wang, L.S.; Tang, W.Z.; Shan, B.Q.; Yang, L.; Chen, J. Effect of storm runoff on the water quality of urban rivers with unconventional water sources. Acta Sci. Circumst. 2015, 35, 443-448.

19. Gan, H.Y.; Zhuo, M.N.; Li, D.Q.; Zhou, Y.Z. The water quality characteristics of runoff on urban road in Guangzhou. Ecol. Environ. Sci. 2006, 15, 969-973.

20. Floresrodrîguez, J.; Bussy, A.L.; Thevenot, D. Toxic metals in urban runoff: Physico-chemical mobility assessment using speciation schemes. Water Sci. Technol. 1994, 29, 83-93.

21. Zehetner, F.; Rosenfellner, U.; Mentler, A.; Gerzabek, M.H. Distribution of Road Salt Residues, Heavy Metals and Polycyclic Aromatic Hydrocarbons across a Highway-Forest Interface. Water Air Soil Pollut. 2009, 198, 125-132. [CrossRef] 
22. Tai, K.C. Flood plain management models for economic, environmental and ecological impact analysis. In Proceedings of the Conference on Ecological Modelling, Copenhagen, Denmark, 28 August-2 September 1978.

23. Cash, R.A.; Halder, S.R.; Husain, M.; Islam, M.S.; Mallick, F.H.; May, M.A.; Rahman, M.; Rahman, M.A. Reducing the health effect of natural hazards in Bangladesh. Lancet 2013, 382, 2094-2103. [CrossRef]

24. Cann, K.F.; Thomas, D.R.; Salmon, R.L.; Wyn-Jones, A.P.; Kay, D. Extreme water-related weather events and waterborne disease. Epidemiol. Infect 2013, 141, 671-686. [CrossRef] [PubMed]

25. ten Veldhuis, J.A.E.; Clemens, F.H.L.R.; Sterk, G.; Berends, B.R. Microbial risks associated with exposure to pathogens in contaminated urban flood water. Water Res. 2010, 44, 2910-2918. [CrossRef] [PubMed]

26. Nguyen, H.Q.; Radhakrishnan, M.; Huynh, T.T.N.; Baino-Salingay, M.L.; Ho, L.P.; Steen, P.V.D.; Pathirana, A. Water Quality Dynamics of Urban Water Bodies during Flooding in Can. Tho City, Vietnam. Water 2017, 9 , 260. [CrossRef]

27. Zhu, J.; Cai, R.H.; He, J. A Guide to the Chinese Core Periodical; Peking University Press: Beijing, China, 2011.

28. Ochoo, B.; Valcour, J.; Sarkar, A. Association between perceptions of public drinking water quality and actual drinking water quality: A community-based exploratory study in newfoundland (Canada). Environ. Res. 2017, 159, 435-443. [CrossRef] [PubMed]

29. Heibati, M.; Stedmon, C.A.; Stenroth, K.; Rauch, S.; Toljander, J.; Säve-Söderbergh, M.; Murphy, K.R. Assessment of drinking water quality at the tap using fluorescence spectroscopy. Water Res. 2017, 125, 1-10. [CrossRef] [PubMed]

30. Abera, B.; Bezabih, B.; Hailu, D. Microbial quality of community drinking water supplies: A ten year (2004-2014) analyses in west amhara, ethiopia. Sustain. Water Qual. Ecol. 2017, 9-10, 22-26. [CrossRef]

31. Bridgeman, J.; Baker, A.; Brown, D.; Boxall, J.B. Portable led fluorescence instrumentation for the rapid assessment of potable water quality. Sci. Total Environ. 2015, 524-525, 338-346. [CrossRef] [PubMed]

32. Emelko, M.B.; Silins, U.; Bladon, K.D.; Stone, M. Implications of land disturbance on drinking water treatability in a changing climate: Demonstrating the need for "source water supply and protection" strategies. Water Res. 2011, 45, 461-472. [CrossRef] [PubMed]

33. Storey, M.V.; Van, d.G.B.; Burns, B.P. Advances in on-line drinking water quality monitoring and early warning systems. Water Res. 2011, 45, 741-747. [CrossRef] [PubMed]

34. Smith, H.G.; Sheridan, G.J.; Lane, P.N.J.; Nyman, P.; Haydon, S. Wildfire effects on water quality in forest catchments: A review with implications for water supply. J. Hydrol. 2011, 396, 170-192. [CrossRef]

35. Mkandawire, T.; Banda, E. Assessment of drinking water quality of mtopwa village in bangwe township, blantyre. Desalination 2009, 248, 557-561. [CrossRef]

36. Cidu, R.; Frau, F.; Tore, P. Drinking water quality: Comparing inorganic components in bottled water and italian tap water. J. Food Compos. Anal. 2011, 24, 184-193. [CrossRef]

37. Macova, M.; Toze, S.; Hodgers, L.; Mueller, J.F.; Bartkow, M.; Escher, B.I. Bioanalytical tools for the evaluation of organic micropollutants during sewage treatment, water recycling and drinking water generation. Water Res. 2011, 45, 4238-4247. [CrossRef] [PubMed]

38. Trinh, H.T.; Marcussen, H.; Hansen, H.C.; Le, G.T.; Duong, H.T.; Ta, N.T.; Nguyen, T.Q.; Hansen, S.; Strobel, B.W. Screening of inorganic and organic contaminants in floodwater in paddy fields of hue and thanh hoa in vietnam. Environ. Sci. Pollut. Res. Int. 2017, 24, 7348-7358. [CrossRef] [PubMed]

39. Nwonumara, N.; Okogwu, O. The impact of flooding on water quality, zooplankton composition, density and biomass in lake iyieke, cross river-floodplain, southeastern nigeria. Acta Zool. Litu. 2013, 23, 138-146. [CrossRef]

40. Mahmood, M.I.; Elagib, N.A.; Horn, F.; Sag, S. Lessons learned from khartoum flash flood impacts: An integrated assessment. Sci. Total Environ. 2017, 601-602, 1031-1045. [CrossRef] [PubMed]

41. Costa, D.; Burlando, P.; Priadi, C. The importance of integrated solutions to flooding and water quality problems in the tropical megacity of jakarta. Sustain. Cities Soc. 2016, 20, 199-209. [CrossRef]

42. Miller, J.D.; Hutchins, M. The impacts of urbanisation and climate change on urban flooding and urban water quality: A review of the evidence concerning the United Kingdom. J. Hydrol. Reg. Stud. 2017, 12, 345-362. [CrossRef]

43. Wallace, J.; Stewart, L.; Hawdon, A.; Keen, R.; Karim, F.; Kemei, J. Flood water quality and marine sediment and nutrient loads from the tully and murray catchments in north queensland, australia. Mar. Freshw. Res. 2009, 60, 1123-1131. [CrossRef] 
44. Mcmillan, M.D.; Rahnema, H.; Romiluy, J.; Kitty, F.J. Effect of exposure time and crude oil composition on low-salinity water flooding. Fuel 2016, 185, 263-272. [CrossRef]

45. Schuch, G.; Serrao-Neumann, S.; Morgan, E.; Choy, D.L. Water in the city: Green open spaces, land use planning and flood management-An australian case study. Land Use Policy 2017, 63, 539-550. [CrossRef]

46. Lintern, A.; Leahy, P.J.; Heijnis, H.; Zawadzki, A.; Gadd, P.; Jacobsen, G.; Deletic, A.; Mccarthyad, D.T. Identifying heavy metal levels in historical flood water deposits using sediment cores. Water Res. 2016, 105, 34-46. [CrossRef] [PubMed]

47. Dortch, M.S.; Zakikhani, M.; Kim, S.C.; Steevens, J.A. Modeling water and sediment contamination of lake pontchartrain following pump-out of hurricane katrina floodwater. J. Environ. Manag. 2008, 87, 429-442. [CrossRef] [PubMed]

48. Wijesiri, B.; Deilami, K.; Mcgree, J.; Goonetilleke, A. Use of surrogate indicators for the evaluation of potential health risks due to poor urban water quality: A bayesian network approach. Environ. Pollut. 2017, $233,655$. [CrossRef] [PubMed]

49. Constantine, K.; Massoud, M.; Alameddine, I.; El-Fadel, M. The role of the water tankers market in water stressed semi-arid urban areas: Implications on water quality and economic burden. J. Environ. Manag. 2017, 188, 85-94. [CrossRef] [PubMed]

50. Feng, T.; Wang, C.; Hou, J.; Wang, P.; Liu, Y.; Dai, Q.; Yang, Y.Y.; You, G.X. Effect of inter-basin water transfer on water quality in an urban lake: A combined water quality index algorithm and biophysical modelling approach. Ecol. Indic. 2017, in press. [CrossRef]

51. Nazemi, A.; Madani, K. Urban water security: Emerging discussion and remaining challenges. Sustain. Cities Soc. 2017, in press. [CrossRef]

52. Minomo, K.; Ohtsuka, N.; Nojiri, K.; Matsumoto, R. Influence of combustion-originated dioxins in atmospheric deposition on water quality of an urban river in japan. J. Environ. Sci. 2018, 64, 245-251. [CrossRef]

53. Xue, Z.H.; Yin, H.L.; Xie, M. Development of integrated catchment and water quality model for urban rivers. Chin. J. Hydrodyn. B 2015, 27, 593-603. [CrossRef]

54. Neto, S. Water governance in an urban age. Util. Policy 2016, 43, 32-41. [CrossRef]

55. Hur, S.; Nam, K.; Kim, J.; Kwak, C. Development of urban runoff model ffc-qual for first-flush water-quality analysis in urban drainage basins. J. Environ. Manag. 2017, 205, 73-84. [CrossRef] [PubMed]

56. Nosrati, K. Identification of a water quality indicator for urban roof runoff. Sustain. Water Qual. Ecol. 2017, 9-10, 78-87. [CrossRef]

57. Scott, A.B.; Frost, P.C. Monitoring water quality in toronto's urban stormwater ponds: Assessing participation rates and data quality of water sampling by citizen scientists in the freshwater watch. Sci. Total Environ. 2017, 592, 738-744. [CrossRef] [PubMed]

58. De Man, H.; van den Berg, H.H.J.L.; Leenen, E.J.T.M.; Schijven, J.F.; Schets, F.M.; van der Vliet, J.C.; van Knapen, F.; de Roda Husman, A.M. Quantitative assessment of infection risk from exposure to waterborne pathogens in urban floodwater. Water Res. 2014, 48, 90-99. [CrossRef] [PubMed]

59. Vardoulakis, S.; Dimitroulopoulou, C.; Thornes, J.; Lai, K.M.; Taylor, J.; Myers, I.; Heaviside, C.; Mavrogianni, A.; Shrubsole, C.; Chalabi, Z.; et al. Wilkinson, P. Impact of climate change on the domestic indoor environment and associated health risks in the UK. Environ. Int. 2015, 85 (Suppl. 1), $299-313$. [CrossRef] [PubMed]

60. Picou, J.S.; Nicholls, K.; Guski, R. Environmental stress and health. Int. Encycl. Soc. Behav. Sci. 2015, 12, 804-808.

61. Chaturongkasumrit, Y.; Techaruvichit, P.; Takahashi, H.; Kimura, B.; Keeratipibul, S. Microbiological evaluation of water during the 2011 flood crisis in thailand. Sci. Total Environ. 2013, 463-464, 959-967. [CrossRef] [PubMed]

62. Harris, R.F. Floodwater challenges. Curr. Biol. 2005, 15, 815-816. [CrossRef]

63. Ashley, N.A.; Valsaraj, K.T.; Thibodeaux, L.J. Elevated in-home sediment contaminant concentrations-The consequence of a particle settling-winnowing process from hurricane katrina floodwaters. Chemosphere 2008, 70, 833-840. [CrossRef] [PubMed]

64. Grigg, B.C.; Beyrouty, C.A.; Norman, R.J.; Gbur, E.E.; Hanson, M.G.; Wells, B.R. Rice responses to changes in floodwater and $n$ timing in southern usa. Field Crops Res. 2000, 66, 73-79. [CrossRef] 
65. Modlmaier, M.; Kuhn, R.; Kaaden, O.R.; Pfeffer, M. Transmission studies of a european sindbis virus in the floodwater mosquito aedes vexans (diptera: Culicidae). Int. J. Med. Microbiol. 2002, 291 (Suppl. 33), 164. [CrossRef]

66. Abbas, H.B.; Routray, J.K. Assessing factors affecting flood-induced public health risks in kassala state of sudan. Oper. Res. Health Care 2014, 3, 215-225. [CrossRef]

67. Waroux, O.L.P.D. Floods as Human Health Risks. In Encyclopedia of Environmental Health; Elsevier Science: Amsterdam, The Netherlands, 2011.

68. Cui, Q.; Fang, T.; Huang, Y.; Dong, P.; Wang, H. Evaluation of bacterial pathogen diversity, abundance and health risks in urban recreational water by amplicon next-generation sequencing and quantitative pcr. J. Environ. Sci. 2017, 57, 137-149. [CrossRef] [PubMed]

69. Crocker, W.; Maute, K.; Webb, C.; French, K. Mosquito assemblages associated with urban water bodies; implications for pest and public health threats. Landsc. Urban Plan. 2017, 162, 115-125. [CrossRef]

70. Renouf, M.A.; Serrao-Neumann, S.; Kenway, S.J.; Morgan, E.A.; Low, C.D. Urban water metabolism indicators derived from a water mass balance-Bridging the gap between visions and performance assessment of urban water resource management. Water Res. 2017, 122, 669-677. [CrossRef] [PubMed]

71. Nel, J.L.; Maitre, D.C.L.; Roux, D.J.; Colvin, C.; Smith, J.S.; Smith-Adao, L.B.; Maherry, A.; Sitas, N. Strategic water source areas for urban water security: Making the connection between protecting ecosystems and benefiting from their services. Ecosyst. Serv. 2017, 28, 251-259. [CrossRef]

72. Fang, T.; Cui, Q.; Huang, Y.; Dong, P.; Wang, H.; Liu, W.T.; Ye, Q. Distribution comparison and risk assessment of free-floating and particle-attached bacterial pathogens in urban recreational water: Implications for water quality management. Sci. Total Environ. 2017, 613-614, 428-438. [CrossRef] [PubMed]

73. Fuhrimann, S.; Pham-Duc, P.; Cissé, G.; Tram, N.T.; Ha, H.T.; Dung, D.T.; Ngoc, P.; Nguyen, H.; Anh Vuong, T.; Utzinger, J.; Schindler, C.; Winkler, M.S. Microbial contamination along the main open wastewater and storm water channel of hanoi, vietnam, and potential health risks for urban farmers. Sci. Total Environ. 2016, 566-567, 1014-1022. [CrossRef] [PubMed]

74. Wang, T.; Xu, Z.; Li, Y.; Liang, M.; Wang, Z.; Hynds, P. Biofilm growth kinetics and nutrient (n/p) adsorption in an urban lake using reclaimed water: A quantitative baseline for ecological health assessment. Ecol. Indic. 2016, 71, 598-607. [CrossRef]

75. Völker, S.; Kistemann, T. Developing the urban blue: Comparative health responses to blue and green urban open spaces in germany. Health Place 2015, 35, 196-205. [CrossRef] [PubMed]

76. Rana, M.D.S. Status of water use sanitation and hygienic condition of urban slums: A study on rupsha ferighat slum, khulna. Desalination 2009, 246, 322-328. [CrossRef]

77. Chanan, A.; Kandasamy, J.; Vigneswaran, S.; Sharma, D. A gradualist approach to address australia's urban water challenge. Desalination 2009, 249, 1012-1016. [CrossRef]

78. Chong, M.N.; Jin, B.; Chow, C.W.; Saint, C. Recent developments in photocatalytic water treatment technology: A review. Water Res. 2010, 44, 2997-3027. [CrossRef] [PubMed]

79. Ellis, J.B.; Marsalek, J.; Chocat, B. Urban Water Quality; John Wiley \& Sons, Ltd.: New York, NY, USA, 2006; pp. 285-292.

80. Sales-Ortells, H.; Medema, G. Microbial health risks associated with exposure to stormwater in a water plaza. Water Res. 2015, 74, 34-46. [CrossRef] [PubMed]

81. Ruin, I.; Creutin, J.-D.; Anquetin, S.; Lutoff, C. Human exposure to flash floods-Relation between flood parameters and human vulnerability during a storm of September 2002 in Southern France. J. Hydrol. 2008, 361, 199-213. [CrossRef]

82. Phan, K.; Sthiannopkao, S.; Kim, K.-W.; Wong, M.H.; Sao, V.; Hashim, J.H.; Yasin, M.S.M.; Aljunid, S.M. Health risk assessment of inorganic arsenic intake of Cambodia residents through groundwater drinking pathway. Water Res. 2010, 44, 5777-5788. [CrossRef] [PubMed]

83. Murray, A.; Ray, I. Wastewater for agriculture: A reuse-oriented planning model and its application in peri-urban China. Water Res. 2010, 44, 1667-1679. [CrossRef] [PubMed]

84. Moglia, M.; Gan, K.; Delbridge, N. Exploring methods to minimize the risk of mosquitoes in rainwater harvesting systems. J. Hydrol. 2016, 543, 324-329. [CrossRef]

85. Yang, S.-J.; Ma, X.; Zhu, G.-F.; Xu, M.; Chen, X.-Y.; Wang, G.-A.; Shi, B.-J. Analysis of the breeding sources of overwintering Aedes albopictus and influencing factors in Ningbo city, 2016. Chin. J. Vector Biol. Control 2017, 28, 69-71. 
86. Intergovernmental Panel on Climate Change (IPCC). Climate Change 2014: Synthesis Report. Available online: http:/ / www.ipcc.ch/report/ar5/syr/ (accessed on 21 February 2018).

87. Xu, Y.X.; Xu, R.Q.; Wang, S.Z. Investigation of the breeding place of mosquito larva in outdoor environmental seeper. Shanghai J. Prev. Med. 2004, 16, 153-156.

88. Pei, Q.-B.; Liu, W.-J.; Zhang, J.-F.; Liu, Q.; Zhao, X.-Y.; Yu, Q.-F. Characterization of Urban Roadway Runoff in Xi'an City. Water Sav. Irrig. 2013, 4, 46-49.

89. Yang, B.; Huang, Y.Q.; Wu, T.; Li, J.J.; Xu, M.L. Research on the Characteristics of Urban Runoff in Zhenjiang: Rainwater Utilization Demonstration Project. Environ. Eng. 2010, 28, 31-35.

90. Li, C.; Tu, X.-J.; Qin, Y.-Q.; Huang, X.-Y.; Hu, Z.-B.; Wei, Q. Analysis of pollutants concentration of initial rainwater in nanning roads. Environ. Eng. 2017, 7, 70-75.

91. Zou, A.-P. Analysis on stormwater management project in Baoan District, Shenzhen City. China Water Wastewater 2010, 16, 71-73.

92. Feng, C.M.; Mi, N.; Wang, X.T.; Cai, Z.W.; Di, W.Z. Analysis of Road Runoff Pollutants in Northern City Based on the Typical Rainfall. Ecol. Environ. Sci. 2015, 3, 418-426.

93. Liu, D.X.; Li, Q.Q.; Li, T.L.; Wang, W.; Jin, C.H.; Yang, Z.Z.; Cao, J.G. Study on the pollution status of rainfall runoff in Tianjin. China Water Wastewater 2015, 11, 116-119.

94. Deng, F.; Chen, W. Probe to the Rainwater Utilization Scheme in Nanjing City Residential Area. China Water Wastewater 2003, 19, 95-97.

95. Jin, G.X.; Wang, P.X.; Qiu, W.G. Rainwater quality monitoring and treatment in Shanghai City. Water Wastewater Eng. 2007, 33, 47-51.

96. Huang, G.R.; Nie, T.F. Characteristics and Load of Non-Point Source Pollution of Urban Rainfall Runoff in Guangzhou, China. J. South China Univ. Technol. Nat. Sci. Edit. 2012, 40, 142-148.

97. Jin, H.W.; Hua, L.; Chen, Y.Y.; Shan, W.J.; Shi, W.X.; Huang, Z.F.; Jiao, Z.Z. The Characteristics of Pollution in Urban Rainwater Pipe Network and Its Influence on the Water Quality of Receiving Water Body. Environ. Chem. 2012, 31, 208-215.

98. Sun, H.; Liu, Z.Q.; Liu, H.H.; Tian, Y. Analysis and Research on the Rainwater Utilization on One Campus of Tianjin. Res. Soil Water Conserv. 2013, 2, 288-292.

99. Shao, H.H.; Li, Y.; Fang, X.J.; Jiang, Z.H. Study on the water quality characteristics of the road stormwater runoff in Beijing City. Water Wastewater Eng. 2011, 37, 130-133.

100. Liu, J.S.; Guo, L.C.; Luo, X.L.; Chen, F.R.; Zeng, Y.P. The Characteristics of Rainwater-Runoff-Flow Pollution Chain in Guangzhou. Environ. Chem. 2014, 33, 1040-1041.

101. Wang, J.X.; Wang, Y.J. Water Quality Analysis and Recycling Suggestions for a Campus in Lanzhou. Water Wastewater Eng. 2013, 39, 151-153.

102. Shen, J.; Li, T.; Qian, J.; Peng, S.H.; Qian, L.P. Types of Detention Tank for Xinghua Drainage System in Hefei City. China Water Wastewater 2012, 28, 40-43.

103. Lin, L.F.; Li, T.; Li, H. Characteristics of Surface Runoff Pollution of Shanghai Urban Area. Chin. J. Environ. Sci. 2007, 28, 1430-1434.

104. Li, M.; Yu, X.J. The analysis of change trend of runoff water quality and recycling methods in Jinan. Environ. Pollut. Control 2008, 30, 98-99.

105. Zhang, N.; Zhao, L.J.; Li, T.L.; Jin, Z.H. Characteristics of pollution and monitoring of water quality in Tianjin. Ecol. Environ. Sci. 2009, 18, 2127-2131.

106. Hou, P.Q.; Ren, Y.F.; Wang, X.K.; Ouyang, Z.P.; Zhou, X.P. Research on Evaluation of Water Quality of Beijing Urban Stormwater Runoff. Chin. J. Environ. Sci. 2012, 33, 71-75.

107. Xu, P.; Si, S.; Zhang, J.Q.; Zhang, Y.J.; Zheng, K.B.; Sun, K.P. Study on control effects of permeable asphalt road and road retention on water quality and quantity of runoff. Water Wastewater Eng. 2015, 11, 64-69.

108. Li, Q.Q.; Li, T.L.; Liu, D.X.; Jin, Z.H. Pollution characteristics of runoff in different function area of Tianjin. Environ. Pollut. Control 2011, 33, 22-26.

109. Zhang, Q.Q.; Wang, X.K.; Hao, L.L.; Hou, P.Q.; Ouyang, Z.Y. Characterization and Source Apportionment of Pollutants in Urban Roadway Runoff in Chongqing. Chin. J. Environ. Sci. 2012, 33, 76-82.

110. Zhang, S.F.; Li, T.; Gao, T.Y. Study on Pollution Load of Urban Surface Runoff in Shanghai. China Water Wastewater 2006, 22, 57-60.

111. Zhu, T.; Zhao, Y.; Che, W.; He, W.H.; Lu, C.Y. Pollution analysis and control countermeasures of rainwater runoff in Hangzhou. China Water Wastewater 2015, 17, 119-123. 
112. Fei, W.; Wang, J.L.; Che, W. Analysis on characteristics of stormwater runoff flush on different land surfaces. Tech. Equip. Environ. Pollut. Control 2012, 6, 817-822.

113. Xie, W.M.; Zhang, F.; Zhang, J.D.; Lin, H. Study on the Change Regularity and Treatment of Urban Rainwater Runoff. Environ. Sci. Technol. 2005, 28, 30-31.

114. Wang, X.H.; Lai, Q.Y.; Du, J.Y.; Bao, Y.S.; Zheng, W.W.; Ye, F.X. Analysis of water quality characteristics of different bedding surface rainfall runoff in ningbo city. Chin. J. Environ. Sci. 2016, S1, 312-316.

115. Wang, Y.H.; Han, Y.; Peng, D.C. Analysis and characteristics of water quality of urban rain runoff. Chin. J. Environ. Sci. 2006, 24, 84-85.

116. Tian, Y.J.; Li, T.; Ye, G.J.; Tang, X.Y. Study on the pollution characteristics of surface runoff in fengqiao industry park of Suzhou. Environ. Pollut. Control 2009, 31, 39-42.

117. Yi, Y.R.; Hai, M.Y.; Zhao, L.L. Analysis on the characteristics of storm runoff water quality of different underlaying surfaces in urumqi. Res. Soil Water Conserv. 2010, 17, 247-251.

118. Chen, Z.R.; Hu, S.; Huang, H.; Li, H. Study on surface runoff pollution in the baimang river basin of shenzhen city. China Water Wastewater 2011, S1, 128-132.

119. Yan, Z.J.; Liu, H.Q.; Sun, H.L.; Zhou, L.Z.; Zhang, M.H. Study on the characteristics of surface runoff pollution in different functional areas in Wenzhou. Environ. Sci. Technol. 2012, S1, 203-208.

120. Xu, W.; Gao, H.J.; Li, T. Pollution Characterization of Impermeability Surface Runoff in Typical Urban of Hefei. Environ. Sci. Technol. 2013, 4, 84-88.

121. Chen, M.; Ren, R.; Wang, Z.J.; Lin, X.T.; Liu, L.L.; Wu, S.H.; Zhang, S.F.; Chen, S. Investigation on Status of Environmental Hormone Pollution in the Industrial Wastewater and Urban Sewage in Beijing. Res. Environ. Sci. 2007, 20, 1-7.

122. Zhang, Y.; Zhang, T.T.; Guo, C.S.; Hua, Z.D.; Zhang, Y.; Xu, J. Pollution Status and Environmental Risks of Illicit Drugs in the Urban Rivers of Beijing. Res. Environ. Sci. 2016, 29, 845-853.

123. Yang, Y.; Wei, Y.S.; Zheng, X.; Wang, Y.W.; Yu, M.; Xiao, Q.C.; Yu, D.W.; Sun, C.; Yang, Y.; Gao, L.J.; et al. Investigation of microbial contamination in Wenyu River of Beijing. Acta Sci. Circumst. 2012, 32, 9-18.

124. Mark, O.; Jørgensen, C.; Hammond, M.; Khan, D.; Tjener, R.; Erichsen, A.; Helwigh, B. A new methodology for modelling of health risk from urban flooding exemplified by cholera-Case Dhaka, Bangladesh. J. Flood Risk Manag. 2018, 11, S28-S42. [CrossRef]

125. Preparing for Extreme And Rare Events in COASTAL REGIONS (PEARL). Available online: http:/ / www. pearl-fp7.eu/ (accessed on 21 February 2018).

126. United States Geological Survey (USGS) Office of Water Quality. USGS Water-Quality Information. USGS Water-Quality Sampling of Flood Waters. Available online: https:/ / water.usgs.gov/owq/floods / (accessed on 21 February 2018).

127. Hawdon, A.; Keen, R.; Kemei, J.; Vleeshouwer, J.; Wallace, J. Design and application of automated flood water quality monitoring systems in the wet tropics. CSIRO Land Water Sci. Rep. 2007, 49, 27.

128. Qiu, X.C.; Zhao, H.X.; Yin, J.; Zhang, W.J. An Analysis of Water Environment Factors and an Evaluation of Water Quality of Aiyi River. China Rural Water Hydropower 2014, 12, 52-55.

129. Li, H.F.; Zhou, L.R.; He, Q.; Li, Y.W. Biotoxicity Analysis of the Gulin River Quality. Ecol. Econ. 2013, 7, 182-185.

130. Li, K.; Wu, S.H.; Dai, E.F.; Xu, Z.C. Flood loss analysis and quantitative risk assessment in China. Nat. Hazards 2012, 63, 737-760. [CrossRef]

131. Yin, J.; Ye, M.W.; Yin, Z.N.; Xu, S.Y. A review of advances in urban flood risk analysis over China. Stoch. Environ. Res. Risk Assess. 2015, 29, 1063-1070. [CrossRef]

132. Li, H.; Ding, L.Q.; Ren, M.L.; Li, C.Z.; Wang, H. Sponge City Construction in China: A Survey of the Challenges and Opportunities. Water 2017, 9, 594. [CrossRef]

133. Nanjing Environmental Protection Agency. Available online: http://www.njhb.gov.cn/43462/43466/ (accessed on 21 February 2018).

134. Chongqing Environmental Protection Agency. Available online: www.cepb.gov.cn/ (accessed on 21 February 2018).

135. Beijing Environmental Protection Agency. Available online: www.bjepb.gov.cn/bjhrb/index/index.html (accessed on 21 February 2018).

136. Guangzhou Environmental Protection Agency. Available online: www.gzepb.gov.cn/ (accessed on 21 February 2018). 
137. Shanghai Environmental Protection Agency. Available online: www.hzepb.gov.cn/ (accessed on 21 February 2018).

138. Hangzhou Environmental Protection Agency. Available online: www.hzepb.gov.cn/ (accessed on 21 February 2018).

139. National Surface Water Quality Automatic Monitoring and Real-Time Data Release System. Available online: http:/ /123.127.175.45:8082/ (accessed on 21 February 2018).

140. AKVO Organization. Available online: https://akvo.org/blog/akvo-caddisfly-a-water-quality-testing-kitfor-sdg-monitoring/ (accessed on 21 February 2018).

141. Gironás, J.; Roesner, L.A.; Rossman, L.A.; Davis, J. A new applications manual for the Storm Water Management Model (SWMM). Environ. Model. Softw. 2010, 25, 813-814. [CrossRef]

142. Deltares Institution. Available online: http://oss.deltares.nl/web/delft-fews/about (accessed on 21 February 2018).

143. Juntunen, J.; Merilainen, P.; Simola, A. Public health and economic risk assessment of waterborne contaminants and pathogens in Finland. Sci. Total Environ. 2017, 599, 873-882. [CrossRef] [PubMed]

144. World Health Organization. Quantitative Microbial Risk Assessment: Application for Water Safety Management, 1st ed.; WHO: Geneva, Switzerland, 2016.

145. Haas, C.N.; Rose, J.B.; Gerba, C.P. Quantitative Microbial Risk Assessment, 2nd ed.; John Wiley \& Sons, Inc.: New York, NY, USA, 2014.

(C) 2018 by the authors. Licensee MDPI, Basel, Switzerland. This article is an open access article distributed under the terms and conditions of the Creative Commons Attribution (CC BY) license (http://creativecommons.org/licenses/by/4.0/). 